\title{
Preparation of Li-B Alloy Battery Anode Material
}

\author{
Xu Xiaojing ${ }^{1}, \quad$ Qu Xuanhui ${ }^{2}, \quad$ Luo Yuanhui ${ }^{1}$ \\ ${ }^{1}$ General Research Institute for Nonferrous Metals, Beijing 100088, China; ${ }^{2}$ University of Science and Technology Beijing, Beijing 100083, \\ China
}

\begin{abstract}
Li-B alloys have excellent potential as a battery anode material, but the difficult preparation limits their commercial application. In the present paper, we improved the synthesis process parameters, including atmospheric control, temperature, cooling, and stirring. Then, we achieved a preparation technique of the $300 \mathrm{~g}$ quantity production. We also obtained the optimum synthesis processing of Li-B alloy under the present experiment condition. Results show that the prepared Li-B alloy is uniform in properties, dense and porosity-free, with advanced discharge capacity in China.
\end{abstract}

Key words: thermal battery; Li-B alloy; anode materials; reaction

Li-B alloys are considered as one of the best anode materials for thermal batteries as they have the nearly same discharge properties as pure lithium, and they are much better than the commonly used Li-Si alloys. With significantly higher melting temperatures, Li-B alloys also overcome the problem that anode material melt into liquid at working temperature (above $400{ }^{\circ} \mathrm{C}$ ). Battery cells fabricated using Li-B alloys have a number of advantages, including small size, light weight, short activated time, high output energy, high specific energy and a long working life.

However, there are severe problems associated with the fabrication and manufacture of Li-B alloys, and these issues have limited their commercial application. Although the Li-B phase diagram is not well established, it is known that several intermetallic compounds form between lithium and boron, and controlling the reaction between the two elements during production of the Li-B anodes is difficult, especially for larger production. Several researchers have examined techniques for the production of these Li-B alloys $^{[1]}$. Wang ${ }^{[2]}$, for example, while producing $100 \mathrm{~g}$ quantities, noted that the initial reaction between liquid lithium and solid boron occurs at about $300{ }^{\circ} \mathrm{C}$, producing $\mathrm{Li}_{3} \mathrm{~B}_{2}$. At the higher temperature of $550{ }^{\circ} \mathrm{C}$, a further reaction occurs, where the $\mathrm{Li}_{3} \mathrm{~B}_{2}$ is converted to $\mathrm{Li}_{7} \mathrm{~B}_{6}$.
When large amounts of $\mathrm{Li}_{7} \mathrm{~B}_{6}$ are produced, a solid skeleton is produced, entrapping any remaining liquid lithium. Szwarc and Dallek ${ }^{[3]}$ achieved a patent for the production of quantities of Li-B as large as $400 \mathrm{~g}$, but reported that bigger batches generated large quantities of heat, making the reaction difficult to control. Kezuza and Iwamura ${ }^{[4]}$ prepared Li-B alloys using a sandwich distillation approach, but reported that the process was unsuitable for mass production. In recent years, Liu et $\mathrm{al}^{[5-8]}$ have also performed research on these alloys, and have successfully synthesized Li-B alloys in laboratory, but only on relatively small batches. It is believed that production quantities as large as $1000 \mathrm{~g}$ have been achieved in recent years, but due to the strategic importance of these alloys, such studies have not been made public.

The aim of the research reported in the present paper is to develop techniques that allow the production of $300 \mathrm{~g}$ quantities of Al-B alloys, and to provide the basis for the industrial production of these materials.

\section{Experiment}

The raw materials used for this study were battery level low-sodium pure lithium ingot (purity $\geqslant 99.99 \%$ ) and amorphous boron (purity $\geqslant 93 \%$ ). The Li-B mixtures were

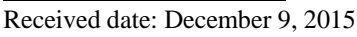

Foundation item: Program for Changiiang Scholars and Innovative Research Team in University of Ministry of Education of China (IZP407)

Corresponding author: Xu Xiaojing, Master, Senior Engineer, Beijing General Research Institute of Nonferrous Metals, Beijing 100088, P. R. China, Tel: 0086-10-69667267, E-mail: xuxiaojing@grinm.com

Copyright $($ ) 2016, Northwest Institute for Nonferrous Metal Research. Published by Elsevier BV. All rights reserved. 
produced in batches of $300 \mathrm{~g}$, using the ratio of $70 \%$ lithium to $30 \%$ boron.

A $3 \mathrm{~kW}$ resistance melting furnace shown in Fig.1 was fabricated in this project. The Li-B alloy was contained in a $150 \mathrm{~mm}$ diameter steel crucible. A paddle fabricated from steel was used for stirring, and thermocouples were employed for temperature monitoring and control. To allow for atmospheric control, the entire melting assembly was enclosed in a steel housing. Several features of the furnace are described below.

(1) Temperature measurement and control

Two thermocouples were used to provide accurate measurement and control of the reaction furnace. A type-K thermocouple, positioned on the outside of the crucible, was used for temperature control. A second sheathed thermocouple was located at the bottom of the stirring paddle to directly measure the temperature of the melt. After stirring, the paddle was raised clear of the melt, but the thermocouple was still immersed to provide additional temperature measurements. In the present paper, all temperatures were measured using the thermocouple attached to the paddle.

(2) Stirring paddle

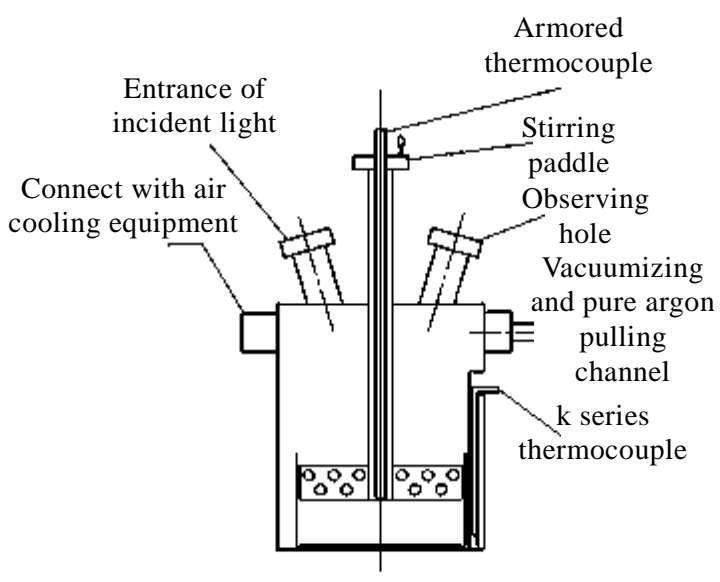

Fig.1 Reaction furnace
The diameter of paddle was slightly smaller than the inside diameter of the crucible. Holes of $8 \mathrm{~mm}$ in size were placed in the paddle. It was found that if the hole size was too large then inadequate agitation would occur, and if the hole size was too small, the intermediate reactant could not pass through the holes, causing the powder to agglomerate.

(3) Observation system

Two observation holes were placed in the steel housing, one to provide illumination of the chamber and the second to directly observe the reaction process. The addition of the observation holes was considered as an essential improvement to procedures used previously ${ }^{[2]}$, as it not only allowed direct observation of the synthesis reaction, which was helpful for understanding the reactions mechanism, but also allowed for adjustment and control of the reaction process.

\section{Melting Studies}

\subsection{Furnace atmosphere}

Atmospheric control during melting and reaction was found to be especially important. For the studies described here, the chamber was initially evacuated below $1.3 \times 10^{-4} \mathrm{~Pa}$ and the furnace was heated to $120{ }^{\circ} \mathrm{C}$ for $1.5 \mathrm{~h}$ to ensure that the boron was completely dry. However, due to the low vapor pressure of lithium, evaporation of lithium is a significant problem when heating in vacuum, so the furnace should be back-filled with argon during further heating. The introduction of the room temperature argon, however, tended to cool the furnace chamber, making temperature control especially important. In addition, if the argon was introduced too early during melting and reaction, porosity is introduced in the castings. For example, Fig.2a shows a SEM photograph of a sample melted under argon, and a large number of small gas pores were observed in the ingot. In contrast, Fig. $2 b$ and $2 c$ show SEM photographs of a sample that was initially melted under vacuum, with the argon being introduced later in the heating process, and this sample is essentially free of porosity.
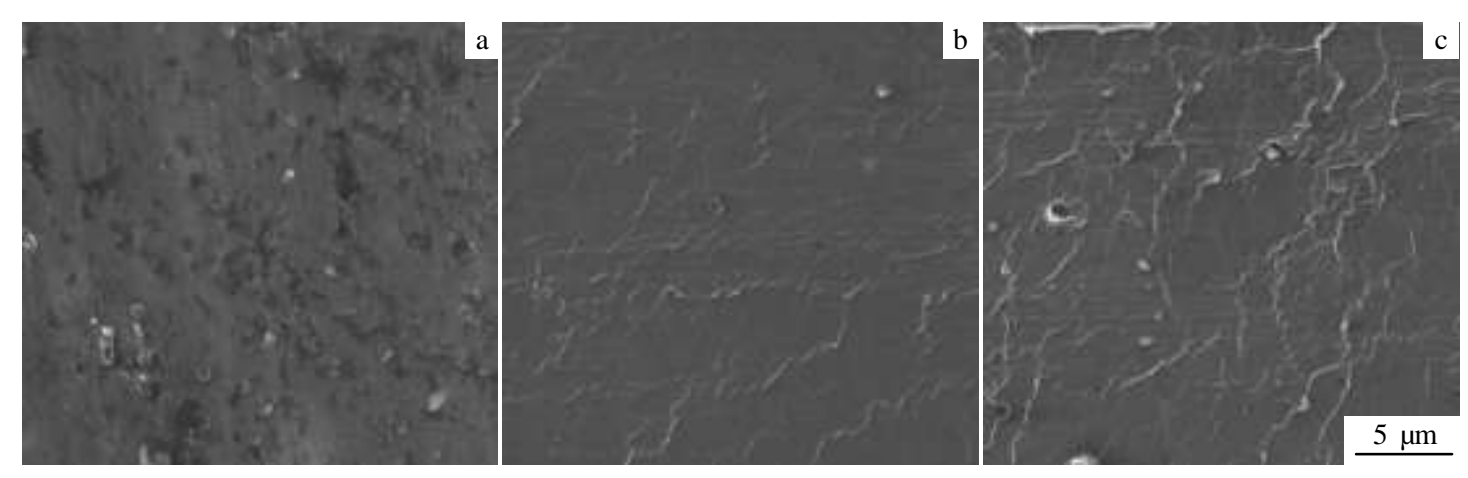

Fig.2 SEM images of ingots produced using different atmosphere: (a) under argon atmosphere, (b) initially using vacuum followed by back-filling with argon (edge), and (c) initially using vacuum followed by back-filling with argon (center) 
This study found that the optimum approach consisted of using a vacuum until the second, higher temperature reaction commences, and the furnace should be back-filled with argon at that stage.

\subsection{Stirring process}

Timing of the stirring is also very important for the successful production of the Li-B material. Stirring is important to ensure the homogeneous distribution of the boron in the liquid lithium. However, if stirring starts before the lithium is completely melted, the paddle tends to break the lithium ingots into small pieces, and the boron powder adheres to the surface of the ingots. This increases the viscosity of the melt, making it difficult to ensure that the boron is homogeneously distributed in the melt.

Stirring also helps with the reaction between the lithium and the boron. Early in the process, a reaction product is formed at the interface between the lithium and the boron, hindering the further reaction. Stirring, however, causes this reaction product to be broken up, and further reaction occurs.

The work described in the present paper examined the influence on the reaction of the different stirring times listed in Table 1, and Fig.3 shows SEM photographs of ingots produced under different stirring conditions. In Fig.3a, the majority of the boron has not reacted, but instead is agglomerated, making further reaction difficult. In Fig. 3b, both the size and number of the boron particle agglomerates have decreased significantly. In Fig.3c, nearly all the boron powder has reacted. However, it was found that a solid skeleton of $\mathrm{Li}_{7} \mathrm{~B}_{6}$ forms above $550{ }^{\circ} \mathrm{C}$, and if stirring is continued above this temperature, the Li-B ingot is fractured, preventing the formation of a complete anode. Based on the results of this study, the best conditions involved starting stirring after the lithium ingots have completely melted and ending stirring when the melt reached $500{ }^{\circ} \mathrm{C}$.

\subsection{Synthesis temperature}

Based on the testing performed in this study, the optimum temperature profile for the production of $\mathrm{Li}-\mathrm{B}$ is shown in Fig.4. The feed materials were initially heated to $120{ }^{\circ} \mathrm{C}$ to drive off any moisture. The furnace was then heated to $300{ }^{\circ} \mathrm{C}$, allowing the first reaction to occur. However, if the temperature is raised too quickly, excessive heat is generated, causing destructive problems. Therefore, the melt was held at $300{ }^{\circ} \mathrm{C}$ for about $2 \mathrm{~h}$. The furnace was then heated to $580{ }^{\circ} \mathrm{C}$ to allow the second reaction to occur. Again, the furnace was held at this temperature to prevent excessive heat generation. However, it was found that temperature also controlled whether or not the reaction went to completion. If the final temperature was too low, the reaction was incomplete. If the final temperature was too high, excessive evaporation of the lithium will occurred, reducing the discharge properties of the anode. This project, therefore, compared the performance of samples with a final temperature of 600 and $700{ }^{\circ} \mathrm{C}$.

The impact of maximum heating temperature on sample appearance can be seen through a comparison of several samples. Fig.5a shows the surface of a sample heated to $600{ }^{\circ} \mathrm{C}$. Though the surface is porosity-free, a small amount of boron has not completely reacted (Fig.3c). When heating to the higher temperature of $700{ }^{\circ} \mathrm{C}$ (Fig.5b), most of the boron reacts although the center of the ingot is porosity-free (Fig. 2b), there is some porosity at the surface (Fig.5b). To ensure all the boron is completely reacted, the optimum temperature to finish heating, therefore, is $700{ }^{\circ} \mathrm{C}$.

\subsection{Cooling}

Cooling of the ingots from the maximum reaction temperature is also important. If the cooling is too fast, the ingot will crack, and complete ingots cannot be obtained. This project, therefore, compared the impact of forced air cooling and furnace cooling on ingot integrity.

Table 1 Stirring times examined in this study

\begin{tabular}{cc}
\hline Beginning of stirring & End of stirring \\
\hline Ingot has completely melted & Melt reached $350{ }^{\circ} \mathrm{C}$ \\
Ingot has completely melted & Melt reached $400^{\circ} \mathrm{C}$ \\
Ingot has completely melted & Melt reached $500^{\circ} \mathrm{C}$ \\
Ingot has completely melted & Melt reached $550{ }^{\circ} \mathrm{C}$ \\
\hline
\end{tabular}

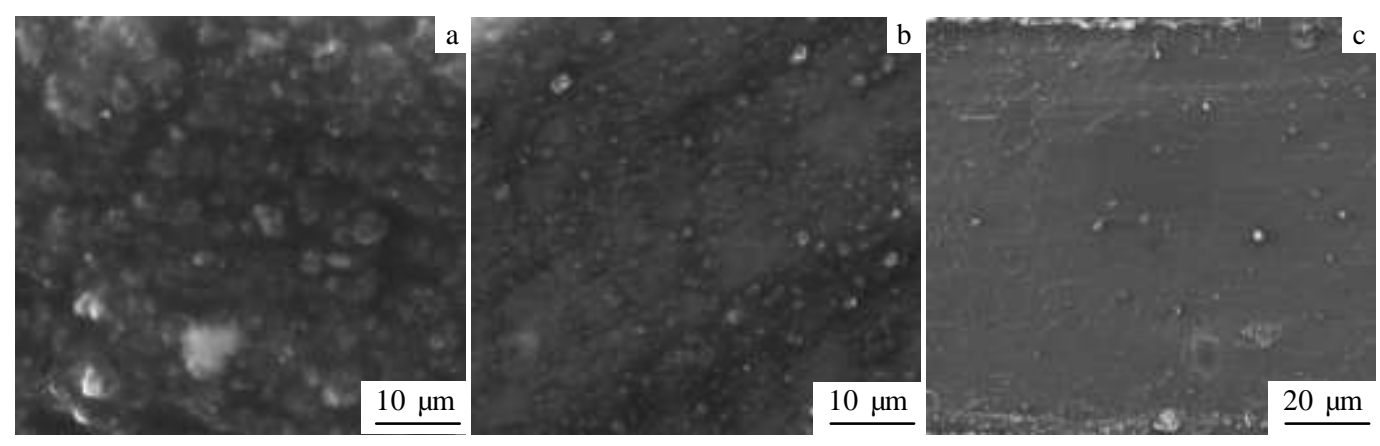

Fig.3 SEM images for different stirring conditions: (a) ending at $350{ }^{\circ} \mathrm{C}$, (b) ending at $400{ }^{\circ} \mathrm{C}$, and (c) ending at $500{ }^{\circ} \mathrm{C}$ 


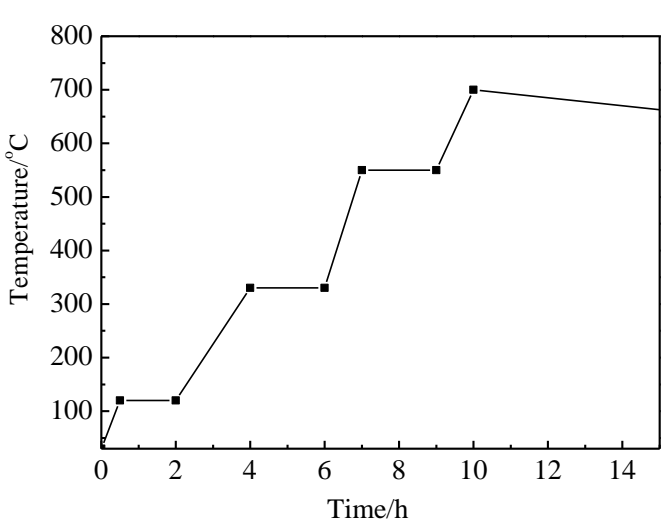

Fig.4 Optimum temperature profile

Fig.6 shows photographs of the ingots cooled using different methods. Fig.6a shows an ingot cooled using forced air, and the ingot obviously cracks into several parts. In contrast, the furnace cooled ingot integrity contains no cracks (Fig.6b), and so furnace cooling is obviously preferable.

\section{Microstructure and Phase Composition of Li-B Alloy}

\subsection{Phase composition}

$\mathrm{X}$-ray diffraction was used to identify the phases present in the reacted ingot. The X-ray diffraction pattern of a representative ingot is shown in Fig.7, indicating that the ingot is composed of $\mathrm{Li}_{7} \mathrm{~B}_{6}$, unreacted metallic lithium, and a small amount of $\mathrm{Li}_{2} \mathrm{O}$.

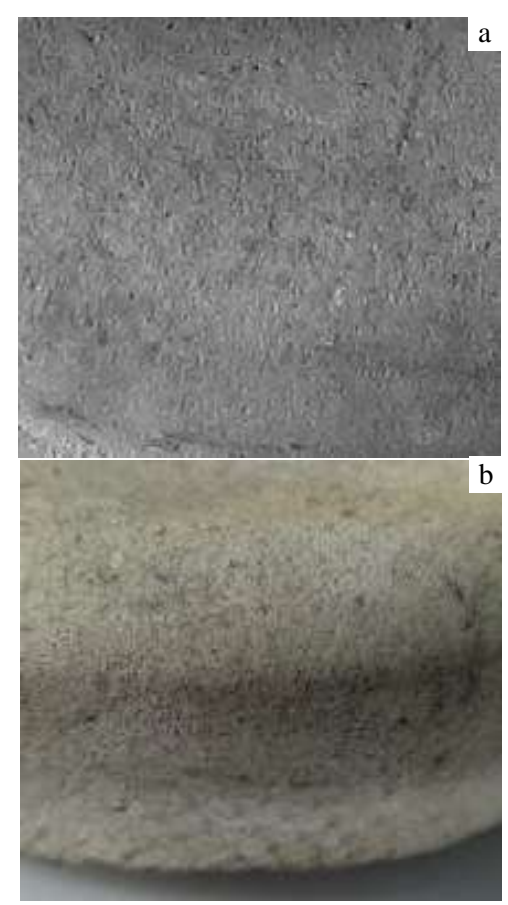

Fig.5 Appearance of samples heated to different temperatures: (a) ending at $600{ }^{\circ} \mathrm{C}$ and (b) ending at $700{ }^{\circ} \mathrm{C}$

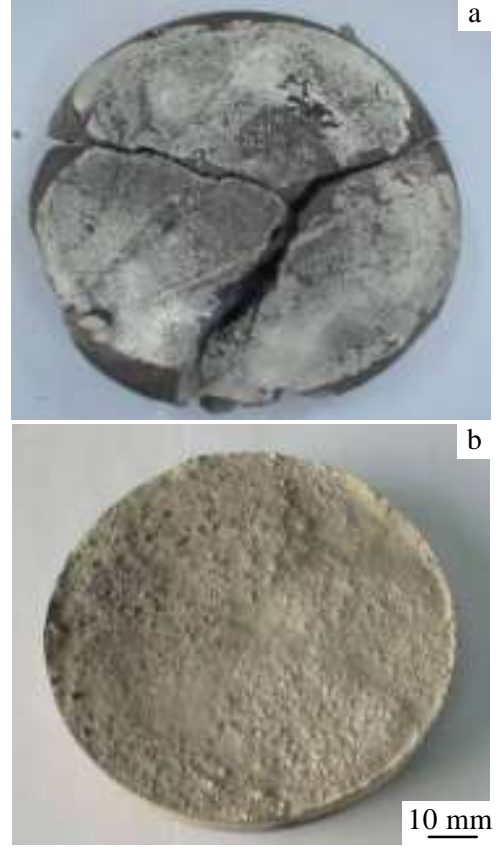

Fig.6 Photographs of the ingots under forced air cooling (a) and furnace cooling (b)

\subsection{Microstructure}

Due to the deleterious impact that moist air has on Li-B alloys, producing samples for optical metallography and SEM analysis is difficult. Fig. 8 shows the microstructure of the Li-B alloy. Examination by energy spectrum analysis shows a high surface oxygen content, indicating that the surface of the Li-B alloy has been oxidized. The oxide is assumed to grow directionally along with the skeleton structure of the alloy. Fig. 8 shows the appearance of the oxide.

An oil protection method was used for the production of the sample shown in Fig.2b. There is no oxidation and the structure is porosity free. It is possible because the Li-B hardness is so low that surface holes are closed by cutter when producing the samples, which hides the porous structure.

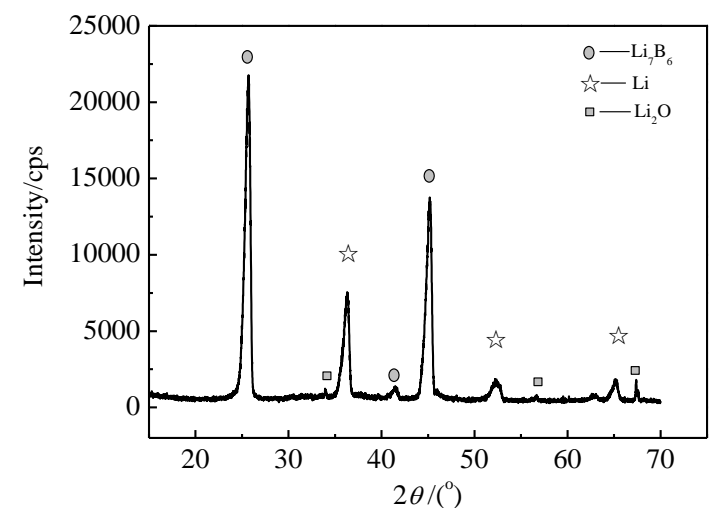

Fig.7 XRD pattern of Li-B ingot 


\subsection{Discharge characteristics of cells}

Fig.9 and Fig.10 show the impact of current density and temperature on discharge properties of a thermal battery cell using a Li-B anode produced in the present study. The first peak at the start of the discharge curve in Fig.9 is caused by the cathode material. Afterwards there is a long discharge plateau, corresponding to the discharge of metal Li in alloy. The second plateau appears when the discharge reaches about $2 / 3$ to $3 / 4$ of total, which corresponds to discharge of ionic $\mathrm{Li}$ in the $\mathrm{Li}_{7} \mathrm{~B}_{6}$ matrix.

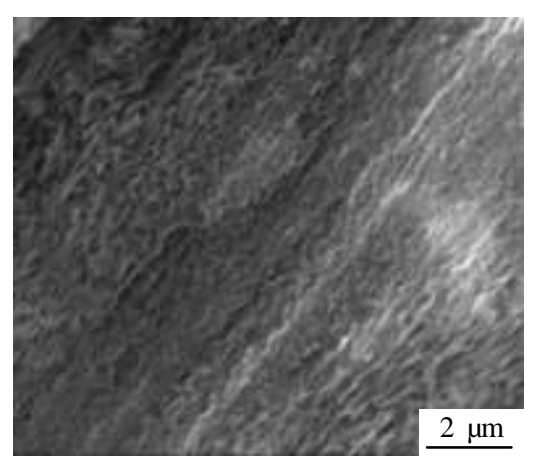

Fig.8 SEM image of Li-B alloy

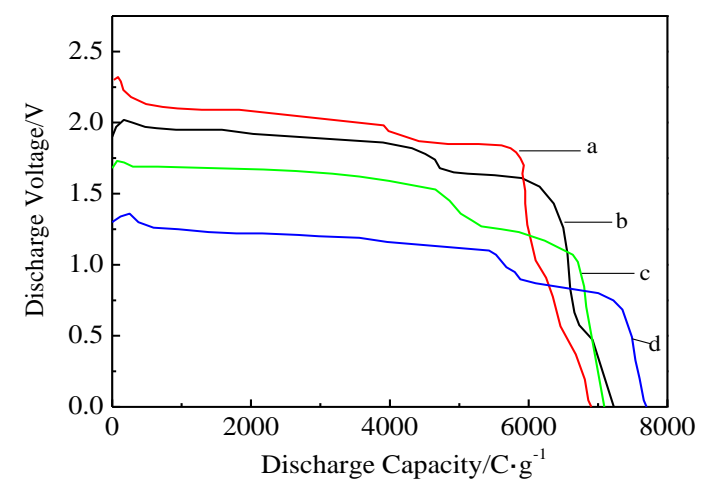

Fig.9 Anode discharge curve of $\mathrm{Li}-\mathrm{B}$ in $\mathrm{LiCl}-\mathrm{KCL}$ at $500{ }^{\circ} \mathrm{C}$ (a-100 mA/cm², b-300 mA/cm², c-500 mA/cm², d-700 $\mathrm{mA} / \mathrm{cm}^{2}$ )

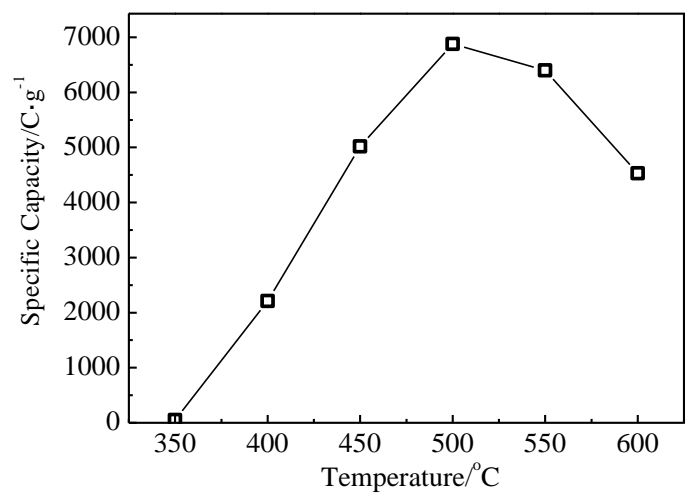

Fig.10 Influences of different temperatures on discharge capacity
From the discharge curve shown in Fig.9, the discharge voltage decreases and the discharge capacity increases with the increasing current. The reason is that the free $\mathrm{Li}$ has a certain solubility in electrolyte $\mathrm{KCl}-\mathrm{LiCl}$, and dissolves easily with increasing the solution of active $\mathrm{Li}$ into the electrolyte. Those ions are continually consumed when they meet cathode and the interface of electrolyte and air. The polarization decreases for the case of high current due to the increase of the number of conductive ions, allowing a higher discharge capacity.

Fig.10 shows that discharge capacity is nearly zero at $350{ }^{\circ} \mathrm{C}$. This is because the melt conducts due to migrating $\mathrm{Li}$ ions, but the melting point of the $\mathrm{KCl}-\mathrm{LiCl}$ electrolyte is $355^{\circ} \mathrm{C}$. In addition, the speed of $\mathrm{Li}$ ions is lower, and concentration polarization decreases at low temperature. Close to the melting point, the ratio of $\mathrm{Li}$ ions and $\mathrm{K}$ ions easily deviates the eutectic arrest at anode, which lead to solidification again and then discharge over. This is why the discharge capacity is low at $400{ }^{\circ} \mathrm{C}$. Concentration polarization decreases with the increasing temperature. Above $550^{\circ} \mathrm{C}, \mathrm{FeS}_{2}$ decomposition produces $\mathrm{S}$, leading to an increase of activation loss. This is the reason why discharge capacity decreases above this temperature.

\section{Conclusions}

1) Using amorphous boron and high purity lithium as the feed materials, and an optimized reaction chamber and experimental practices, a $300 \mathrm{~g}$ batch of Li-B alloy has successfully been prepared.

2) The best preparation process for the Li-B alloy is achieved using the following approach: (1) The optimum atmosphere for the reaction furnace maintains a good vacuum until the second reaction between $\mathrm{Li}$ and $\mathrm{B}$ commences and then back-fills the chamber with argon. (2) The best stirring procedure starts stirring once the Li ingot is completely melted and ending stirring when the reaction mixture reaches $500{ }^{\circ} \mathrm{C}$. (3) The best synthesis ending temperature is $700{ }^{\circ} \mathrm{C}$. (4) Once the reaction is complete, it is best to slowly cool the ingot in the furnace.

3) The cell's discharge capacity reaches a maximum at $500{ }^{\circ} \mathrm{C}$ and the discharge voltage decreases, discharge time declines and discharge capacity increases with increasing current density.

Acknowledgement: thanks to Professor Qu Xuanhui for his encouragement and support; thanks to Dr. Steve Midson for his compressive language correction.

\section{References}

1 Meden A, Pihlar B, Pejovnik S. J Appl Electrochem[J], 1994, 24(1): 78

2 Wang F E. Metal Mater Trans A[J], 1979, 10(3): 343

3 Szwarc R, Dallek S. US Patent, DE82015798[P]. 1978

4 Kezuza H, Iwamura K. Applications of Surface Science[J], 
1982, 11-12: 144

5 Liu Zhijian, Tang Huafen, Li Zhiyou et al. Metallic Functional Materials[J], 1998, 5(5): 222 (in Chinese)

6 Liu Zhijian, Qu Xuanhui, Li Zhiyou et al. Scientia Sinica Technologica[J], 2003, 33(7): 597 (in Chinese)
7 Liu Zhijian, Duan Wei, Huang Yinhua et al. Journal of Functional Materials[J], 2000, 31(1): 60 (in Chinese)

8 Liu Zhijian. Thesis for Doctorate[D]. Changsha: Central South University, 2000: 25 (in Chinese)

\title{
热电池阳极材料 Li-B 合金制备工艺研究
}

\author{
许小静 ${ }^{1}$, 曲选辉 ${ }^{2}$, 罗远辉 ${ }^{1}$ \\ (1. 北京有色金属研究总院, 北京 100088) \\ (2. 北京科技大学, 北京 100083)
}

\begin{abstract}
摘 要: Li-B合金是一种性能优良的热电池用阳极材料, 由于合成制备困难制约了它的应用。通过对合成过程中气氛、摚拌、温度控制、 后处理等工艺进行有效改进, 获得了 $300 \mathrm{~g} /$ 炉的制备规模, 得出了本实验条件下制备Li-B合金的最佳工艺, 所制备的合金均匀致密, 放 电性能达到国内先进水平。
\end{abstract}

关键词: 热电池; Li-B 合金; 阳极材料; 制备工艺

作者简介: 许小静, 女, 1982 年生, 硕士, 高级工程师, 北京有色金属研究总院, 北京 100088, 电话: 010-69667267, E-mail: xuxiaojing@grinm.com 